\title{
The Utilization of Google Classroom in Implementing Distance Learning in Islamic High School Al Azhar 9 of Yogyakarta During Covid -19 Pandemic
}

\author{
$1^{\text {st }}$ Rahmad Sugiarto* \\ History Department \\ University State of Yogyakarta \\ Yogyakarta, Indonesia \\ Rahmad010@gmail.com
}

\author{
$2^{\text {nd }}$ Aman \\ History Department \\ University State of Yogyakarta \\ Yogyakarta \\ aman@uny.ac.id
}

\begin{abstract}
The current learning process has entered the era of the industrial revolution 4.0 where information technology plays an important role in the learning process. Nowadays almost all parts of the worlds are currently facing a covid-19 pandemic whose spread is truly massive and rapid. The impact of the Covid - 19 pandemic was extraordinary and had an effect on various aspects of human life. The covid-19 pandemic directly or indirectly affect on many sectors namely healthcare system, economics, social and education as well. With the occurrence of these events, the government through the Ministry of Education issued a policy, that learning activities carried out at home or learning is carried out remotely, this applies from the start of primary and secondary education. With this policy, it is hoped to break the chain of spread of the Covid - 19 virus among people. With the responsibility as an educator who is at the forefront of the learning process, many teachers executed the implementation of teaching and learning activities which carried out online through online system. There are several application options that are used to support learning, one of which is using Google classroom. This paper discussed the process of planning, implementation, evaluation of distance learning. Google Classroom Usage Assessment System was carried out after students submit the assignments, which carried out directly using the assessment content in the Google Classroom application. Posttest done by the student was then immediately corrected by the teacher with an average grade of 73.35. If seen from the average number it is indeed above the minimum completeness criteria (CCM), which is 73.00. After the whole value which includes the final cognitive value,the observation value of student activity, the value of the structured assignment, and the posttest was processed, the final grade is obtained. The result showed 20 students or $95.00 \%$ completed the final grade. The average cognitive value of the final grade achieved is 77.46.
\end{abstract}

Keywords: Google classroom, distance learning, information technology

\section{INTRODUCTION}

Education is one of the processes to prepare young people in facing global competition. Education greatly affects the welfare of the community, because with high education society will be able to improve the quality of good human resources and good human resources will increase one's dignity and dignity in society. With education, it is expected that humans can develop their full potential or talents. From time to time with the increase of development in this digitalized era, education is very important to support the increased open competition in developed countries. In this case not only the teacher who plays the most important role, but also the media for the delivery of learning also has a very important position, the instructor is indeed the spearhead in educating students to become an expert in their field. But if society only rely on a teacher without considering how to make the innovation of education, it does the same with conventional education system. Thus, in this digital era a teacher needs new strategies to be able to maximize learning. To achieve this goal, the instructor must have professionalism and expertise in their respective fields and expertise in the digital field in order to keep abreast of the times. With the existence of globalization the learning process begins to change from conventional to digital and to achieve this goal, we need a form that is able to support the improvement of knowledge in the field of Information Technology and Communication [1].

Nowdays there are already many different kinds of educational programs or applications that do not always have to be done through face-to-face in class which often known as distance learning. Some examples of application for distance learning are edomundo, icando, meja kita, etc. But one application that considered as one of the best options because it has complete content, tools and facility for distance learning nowadays is Google Classroom.

Globalization brings the latest innovations related to the digital era, hence the education field is also affected by those innovations. Education in the digital age is education that can integrate Information and Communication Technology into all subjects. With the development of digital age education, it allows students to get abundant knowledge quickly and easily.

Digital education is also a concept / way of giving lessons to students by using multi media such as using computer aids, gadgets, audio, visuals, and a combination of audio and visual that is video. The way of learning is different from conventional education, where students are given the opportunity to interact and be creative. Thus students really like the lessons they received. In addition 
students can also study at home by bringing the subject matter provided by instructors in the form of e-learning (ebooks, e-modules and so on) and some help of distancelearning software [2].

In the digital age, it is easier for students to learn, for example in terms of the material delivery using multimedia. Learning no longer used a conventional whiteboard but it uses a projector screen to display material. The material displayed can be in the form of photos, videos, animations and others, with these materials the information delivered will be more real hence students will more easily capture the contents of the material presented [3].

The learning process today is different from the past where classes are always held directly (face to face) in the classroom. With the development of IT (Information Technology), there are many applications and websites that can be used as supporting media to replace the learning process in the classroom as discussed above, namely Distance Learning. The design of Google Classroom is familiar to students because they already use several products from Google via their Google Apps account. Students really like how connectivity between Google Classroom and Google drive accounts can be easily used and operated. They do not need to worry about storing documents in the class computer because the auto save feature and the use of Drive make the tasks easier to store and organize [4].

However, several distance learning programs even still use computers to access while the cost to build a personal computer is quite expensive when compared to smartphones that the majority of students already have. In addition, because of its application google classroom can be accesed and used using a smartphone. This benefit makes Google classroom appears very flexible so that it can be accessed anytime and anywhere without being impeded by time and space [5].

Distance learning at schools at all levels of education is already underway. Since most of us experience the outbreak of covid-19 pandemic thus the distance learning becomes current solution. Without distance learning, there are difficulties in terms of making several adjustment in teaching during the covid-19 pandemic. Google Classroom is needed to anticipate the busy life of educators to keep learning going.

With this research it is expected that educators can continue to teach in their daily basis, and students are no longer burdened by distance, space, and time. Because with the use of Google Classroom, students can take lessons outside the classroom when teachers cannot attend the class or are replaced with assignments and various important announcements that can be accessed through Google Classroom through their gadgets.

\section{Understanding Online Learning or E-learning}

The word online comes from English, the opposite of the word from online is offline. Online and offline have certain meanings in terms of computer and telecommunications technology. In general, online shows the state of being connected, while offline shows the state of being disconnected. Online can also be interpreted as state of using computers that make the users are able to exchange information because it is connected to an internet connection. This concept has been extended from the meaning of computerization and telecommunications into the field of human interaction and conversation, in such a way that even offline can be used in contrast to general online use. While learning comes from English which has the meaning of general learning is a process, method, act of making people or living things learn. Online learning in daily life is often referred to as e-learning, it is because both have almost the same meaning, e-learning comes from a combination of two words Electronic Learning, which means: Electronic learning system or e-learning (English: Electronic learning abbreviated E-learning) can be defined as a form of information technology that is applied in education in the form of websites that can be accessed anywhere. E-learning is the basis and logical consequence of the development of information and communication technology. With e-learning, students (teamers) do not need to sit in the classroom to listen to every statement from an educator directly [6].

Many experts proposed several terms of online learning, namely e-learning, online learning, internet-enabled learning, virtual learning, or web-based learning. E-learning can also shorten the target schedule of learning time, and of course save costs that must be incurred by a study program or educational program. E-learning has a long history, Elearning or electronic learning was first introduced by the University of Illinois at Urbana- Champaign by using a computer-assisted instruction system and the PLATO computer. Since then, the development of E-learning from time to time is as follows [6].

a. 1990: The era of CBT (Computer-Based Training) where began to emerge e-learning applications that run on standalone personal computers (PCs) or in the form of CD- ROM packaging. Fill material in written or multimedia form (video and audio) in mov, mpeg-1, or avi format.

b. 1994: Along with the acceptance of CBT (ComputerBased Training) by the community, since 1994 CBT appeared in the form of packages that were more attractive and mass produced.

c. 1997: LMS (Learning Management System). Along with the development of internet technology, People in the world are connected to each other through internet. The need for duplicate, fast-paced information accounts began to be felt as an absolute necessity, and distance and location were no longer obstacles.

Forms of standards emerge, for example, standards issued by AICC (Airline Industry CBT Committee), IMS, SCORM, IEEE LOM, ARIADNE. In 1999 the Webbased E-learning application was developed, particularly LMS towards Web-based e-learning applications was developing, both for learners and learning administration. LMS began to be combined with information sites, magazines, and newspapers. The contents were also increasingly rich with a mix of multimedia, video streaming, and interactive appearances in a variety of data formats that are more standard, and smaller.

Technology in education field today has significantly developed. The development of this technology aims to improve facilities that are able to make education better. One of the most developed educational technologies is E- 
Learning and Online Learning, because the technology is expected to be able to solve learning problems.

e. E-Learning is teaching and learning that uses electronic circuits (LAN, WAN, or internet) to convey content. From the opinion, it appears that teaching and learning are all done in the classroom. However, from time to time, the face to face teaching style was replaced by e-learning that uses electronic media. It is a form of learning that utilizes the internet connection; thus, it is able to facilitate students to learn outside the classroom. The development of E-Learning is intended to overcome problems in learning that require face to face meeting between the instructor and students. In the conventional learning process sometimes the time allocated for learning in the classroom is not enough to discuss the whole learning material. For this reason, it can be argued that learning process needs media that can be accessed at all times by students without having to be in the classroom and provide learning materials that are in accordance with basic competencies.

\section{RESEARCH METHOD}

The form of this research was descriptive qualitative research considering that this research emphasized more on activities and information about the ongoing situation, process and meaning of distance learning. The data collected was mainly in the form of words, sentences, or images that have more meaningful meanings and are able to spur the emergence of a more tangible understanding than merely serving numbers or frequencies. The researcher emphasized notes with detailed, complete, and in-depth sentence descriptions that describe the actual situation to support the study of the data. [7].

This study aims to explored the use of the google classroom application in school affected by Covid-19. Research data were collected through observation, document analysis, and interviews. This study used qualitative method because researchers intend to dig and described the problem of distance learning in a history class, ranging from teaching preparation, learning implementation, to learning evaluation. [8].

\section{RESULT}

\section{a. Understanding Google Clasroom}

Google Classroom is a mixed learning foyer intended for every scope of education purpose to resolve difficulties in making, sharing and classifying each paperless assignment. This software has been introduced as a feature of Google Apps for education, then began to be used by public since August 12, 2014. According to the official website from Google, the Google Classroom application is a free productivity tool including e-mail, documents and storage. Google Classroom is designed to facilitate educators to save time effectively, and to manage classes and improve communication with students easily. By using google classroom, the purpose is facilitating students and educators to have easy connectivity while implementing distance learning. Both students and teachers can communicate beyond offline meeting in schools so that miscommunication between students and educators does not often occur.
To use this service, both teachers and students need to have their own e-mail or ID (ID) accounts, so that teachers can control students directly. Google Classroom is a learning management system for schools with the aim of making paperless assignments, distributions and assessments become easier. Google Classroom acts as a media or supporting tool that can be used by teachers and students to create online classes or classes virtually, where teachers can provide announcements or assignments to students that are received directly (real time) by these students.

For Google Classroom, the system used is not only the website but also in the form of applications that can be used in smartphones where the accounts of students will log in continuously so that if instructors provide material, assignments or announcements, students can receive notifications automatically. Google Classroom is designed to help teachers create and collect paperless assignments, including time-saving features such as the ability to automatically make copies of documents for each student. This electronic class can also create a storage folder for each assignment and each student, so that everything is well organized. Students can track each task that is almost close to the deadline for collection on the assignment page, and start working on it with just one device. Educators can quickly see who has not completed the assignment, as well as provide direct feedback and grades in electronic classes.

\section{b. Planning}

Planning is the relationship between what is now (what is) and how it should (what should be) related to the needs, setting goals, priorities, programs, and allocations. Planning is the preparation of making decisions in the form of steps to solve a problem or the implementation of a work directed at achieving certain goals [9]. Planning is determining what will be done. Planning contains a broad set of decisions and explanations about objectives, determining policies, determining programs, determining certain methods and procedures and determining activities based on daily schedules. Planning is determining the work that must be carried out by the group to achieve the objectives outlined [10].

\section{c. Significance}

Significance can be interpreted as meaningfulness. The significance value means that planning should be meaningful so that the process of implementing Google Classroom runs effectively and efficiently. It is intended that at the time of its application later this planning can be used as a guide.

\section{d. Certainty}

The value of certainty means that in planning there is certainty that serves as a guide in organizing the process learning using Google Classroom in Schools and it is divided into several parts;

a) Introduction to Google Classroom which contains a number of things, such as; virtual classes, notifications, online exams and test assessments, assignment collection and assessments, announcements, Google Drive storage.

b) Required for students to have mobile phone or gadgets with at least 512 megabite RAM gigabite memory. 
c) Creating a Google Classroom account for students and educators. The account used in Google Classroom is a G- mail account.

d) Log in as learners and educators. Log in is divided into two categories; first, students are encouraged to join online classes that have been made by educators. Second, after $\log$ in on the class that was created educators provide information related to the assignment and code so students can join the class.

e) Implementation of the use of Google Classroom can be described as: "Putting into practice of an idea, program or set of activities which is new to the individual or organization who using it". Implementation of Google Classroom is an activity to practice / implement an idea, program or set of new activities for individuals or organizations [11].

Design and implementation are a system and form that have a straight line in relation (the concept of linearity in the sense reflects design of implementation, so it is very important for educators and other field actors involved to understand the teaching and learning process[12]. To conclude it is important to understand the design properly and correctly. In this research, the implementation of distance learning using Google Classroom was carried out on March 16, 2020, while the implementation steps are as follows.

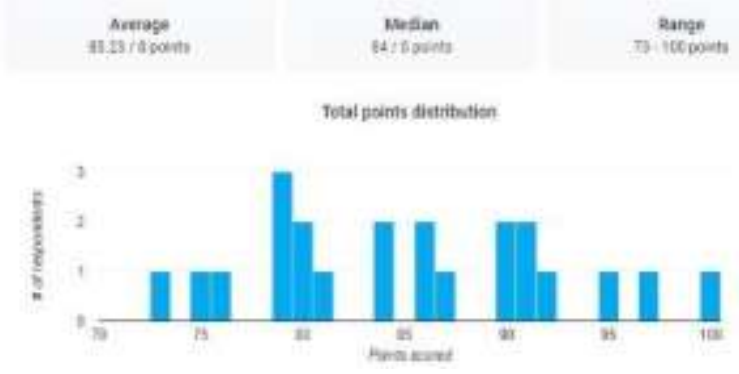

a) Researcher made preparations related to the initial activity of using the Google Classroom application on the History subject in class X IPS.

b) Researcher as educator made announcement as a form of initial use of the Google Classroom application in History subject. The initial use was giving announcement related e-learning plan execution. Researcher observed the response and effectiveness of using Google Classroom application.

c) Researcher made the assignments as a form of evaluation on historical subject through the Google Classroom application. The assignment was done on March 23, 2020, the task contains a picture, video, explanation, and there were some questions in it, and the provisions of the collection or deadline of students' tasks. The task has a purpose to explore students' understanding about the meaning of all video, picture and its explanation, and answer the questions in column that was already provided. The assignment was successfully sent and students received notification of the assignment.

d) Students received and worked on the assignment. Students sent the result of their work.

e) Educators received notifications related to students who have submitted assignments. The assignment of students was received by educators on March 26, 2020. The majority of students submitted the assignments before the deadline for collection. Although there were some students who were late submitting their assignments which passed the specified time limit.

Google Classroom Usage Assessment System is carried out after students submit the assignment. Meanwhile the assignment was carried out directly using the assessment content in the Google Classroom application.

Assessment was done using numerical variables, which assessment variables can be set by educator. For example, educators can decide and set for the biggest score either using 100-scale or 10-scale. After delivering the material, the teacher held a post-test. Posttest done by the student is then immediately corrected by the teacher with an average grade of 73.35. If seen from the average number it is indeed above the minimum completeness criteria (KKM), which is 73.00. This average has exceeded the KKM threshold. Meanwhile out of the 22 students who worked on the posttest questions, there were 2 students who had not yet completed with an average grade of 65.00. The student who received the highest score was an acquisition of 80.00 . While the students who got the lowest score were with 63.00 acquisition.

The final cognitive value was obtained based on the average value of observation of student activity, structured assignments, and post test scores. After the whole value was reached which includes the observation value of student activity, the value of the structured assignment, and the posttest value is processed, the final grade is obtained. Of the 22 students, as many as 20 students or $95.00 \%$ of the class has completed the final grade and 2 students or $2.78 \%$ did not complete the final grade. The highest final value was 83.67, while the lowest final grade was 69.33 The average cognitive value of the final grade achieved was 77.46 .

Assessment has done after students submit the assignments, and it was directly carried out using assessment content which was available on the google classroom application. From the student and teacher interviews about the data obtained several factors supported the use of google classroom:

a. The school allows students to bring smart phones.

b. The school facilitates the use of the internet in the learning process.

c. All students in class have a smart phone.

d. Google classroom application features are more complete than other learning applications.

e. Google Classroom is easy to be used by almost all students.

f. Google classroom application can be accessed anytime and anywhere.

g. Google Classroom facilitates the teacher in delivering material.

h. Google Classroom facilitates the teacher in the assessment process.

However, some obstacle was still found during the implementation of Google Classroom, namely poor internet access and its signal that is unstable. So when using the google classroom application it is slightly hampered due to bandwidth limitations. Browsing activities to find information data was also hampered because due to this poor connection problems. 


\section{CONCLUSION}

From the data obtained systematically it can be concluded as follows; Planning that has been made was good and sufficient, because the plan to provide distance learning support to students has been successfully achieved. The steps taken were already sufficient and well-managed in the sense of being in accordance with what has been planned, through the stages of planning, implementation / use, evaluation, and follow-up. The results of this study showed there are changes in the level of understanding of the material and the activeness of learning in students between conventional learning and the use of Google Classroom learning media.

The subject which was provided through the application was good, which is in accordance with the conditions of the times and the school environment. The activeness of the students was good, as it can be seen from the way students being able to formulate problems or questions related to the material provided. Moreover, the quality of the learning process was quite good, in the sense that educators can provide a more concrete description of the material through images, animations, and videos. Evaluation/ assessment related to the tasks given by educators through Google Classroom was also successfully made, this can be seen from the assessments which made using numeric variables. From the description of the data above we can sum up that the learning assessment system using Google Classroom as a whole is good, beneficial and suitable to support distance learning when the covid-19 pandemic occurs in the current situation.

\section{REFERENCES}

[1] Uno H, 2016:59), Sejarah Perkembangan Teknologi, Bumi aksara, Jakarta, 2016, pp. 59.

[2] Cecep Kustadi, Media pembelajaran manual dan digital, Bogor, Ghalia Indonesia 2013. pp. 56.

[3] Cecep Kustadi, Media pembelajaran manual dan digital, Bogor, Ghalia Indonesia 2013. pp. 72.

[4] Website Google Classroom, 2014. (Accessed April 10, 2020).

[5] Cecep Kustadi, Media pembelajaran manual dan digital, Bogor, Ghalia Indonesia 2013. pp. 61.

[6] Wikipedia, 2015. (Accessed April 10, 2020).

[7] HB Mustopo, Metodologi Penelitian Kualitatif (Dasar Teori dan Terapannya dalam penelitian), Surakarta, 2006. Pp. 24.

[8] Cook, T. D., Campbell, D. T., \& Day, A. (1979). Quasiexperimentation: Design \& analysis issues for field settings (Vol. 351). Boston: Houghton Mifflin.

[9] Hamzah Uno, Teori Motivasi \& Pengukurannya: Analisis di Bidang Pendidikan. Jakarta, Bumi Aksar, 2016. pp. 32.

[10] Terry Abdul Majid, Perencanaan Pembelajaran Mengembangkan Standar Kompetensi Guru, Bandung, PT Remaja Rosdakarya, 2016. Pp 16.

[11] Tindaon, Yosi Abdian. 2012. Pengertian Kemampuan Menulis. Diunduh tanggal 11 april 2020 di http:// pengertian-kemampuanmenulis.html/
[12] Miller, Seller, Prinsip Dasar pengembangan kurikulum. Bandung, PT. Remaja Rosdakarya 1993. Pp. 84. 